\title{
Microbial Activity in Lake Sediments with Particular Reference to Electrode Potential Gradients
}

\author{
By J. GWYNFRYN JONES \\ Freshwater Biological Association, The Ferry House, Ambleside, Cumbria LA22 0LP
}

(Received 11 January 1979)

\begin{abstract}
Microbial activity was determined along electrode potential gradients within sediments, and along sediment surfaces in a stratified eutrophic lake. There was evidence of a change from a tricarboxylic acid cycle-based metabolism to a fermentative one with decreasing electrode potential. A more detailed examination of the stratification of the microbial community showed that the activities of enzymes associated with energy metabolism (in this case electron transport) were highest on electrode potential gradients. This was observed within a sediment core on a millimetre-depth scale, as well as over several metres at the surface of sediments, on a transect which ran from oxic littoral muds to the anoxic profundal zone. In contrast, microbial hydrolytic enzymes, such as protease and amylase, were most active at the sediment surface, where the highest concentrations of substrates might be expected.
\end{abstract}

\section{INTRODUCTION}

The bacterial populations in the water column of a lake fluctuate in response to a number of variables. Correlations with phytoplankton populations in the epilimnion (Overbeck, 1968; Jones, 1972) and, in shallow eutrophic lakes, with increasing nutrient concentration in the anoxic hypolimnion (Jones, 1977) have been demonstrated. Peaks in the bacterial population have also been observed in the metalimnion, the zone of temperature gradient between the surface water and the deeper cooler water in a stratified lake. In shallow eutrophic lakes this zone also comprises the oxycline and chemocline (gradients of dissolved oxygen and certain inorganic nutrients) particularly during late summer. High plate counts of bacteria in this region were attributed by Collins \& Willoughby (1962) to populations carried by inflowing streams in spate, whose temperatures often corresponded to that of the metalimnion. Overbeck (1975) considered the metalimnion to be a region of high metabolic activity, possibly related to decomposition of the remains of primary producers sedimenting out of the epilimnion. Certain specific groups of bacteria may also find optimum conditions for growth on the chemocline (e.g. iron bacteria; see Jones, 1978) where there is sufficient oxygen from the water above and mineral nutrients from the anoxic water below. The depth of the growth zone at any given time will depend on the degree of turbulence in the water.

Bacterial numbers and activity in lake sediments are usually about three orders of magnitude higher than in the water column and their activity is such that its influence is detected in the overlying water. The electrode potential $\left(E_{\mathrm{h}}\right)$ discontinuity layer gradually moves upwards as the sediments of eutrophic lakes become anoxic (Mortimer, 1941) and eventually enters the water column. This, in turn, will affect the distribution and activity of bacteria such as methanogens and sulphate-reducers in the sediments. Microbial communities in sediments have been sampled at comparatively broad depth intervals (e.g. Johnston \& Cross, 1976; Vosjan \& Olanczuk-Neyman, 1977; Wieser \& Zech, 1976) and a steadily 
decreasing activity and population size with depth has been observed. Vertical stratification of populations such as denitrifiers, sulphate-reducers and methanogens within the microbial community has, however, been observed and the importance of $E_{\mathrm{h}}$ gradients as sites of high metabolic activity has been recognized (Fenchel \& Jørgensen, 1977). The purpose of this study was to examine the metabolic activity of micro-organisms along $E_{\mathrm{h}}$ gradients in more detail.

\section{METHODS}

Sampling. Sediment samples were taken from the North Basin of Windermere and from Blelham Tarn with a Jenkin surface mud corer and were sub-sampled on extrusion using the device described by Jones (1976). This allowed samples to be taken at $2 \mathrm{~mm}$ depth intervals. Temperature and dissolved oxygen were recorded in the field on a combination thermistor/oxygen electrode (Mackereth, 1964). The electrode potential of the sediment in the core was measured at $1 \mathrm{~mm}$ depth intervals with a bright platinum electrode and a fast-flow calomel reference electrode. The platinum electrode was constructed from $0.46 \mathrm{~mm}$ diam. wire which was flattened at the tip to produce a horizontal blade approximately $1.5 \times 4 \mathrm{~mm}$. The wire was inserted into the tip of a Pasteur pipette and held in place by epoxy resin (Araldite, Ciba-Geigy). Contact between the platinum and a copper lead was via a mercury plug in the pipette. The electrode blade was polished with fine alumina (about $0.05 \mu \mathrm{m}$ grain size) and the couple was tested in ZoBell's solution (3.3 mM-potassium ferro- and ferricyanide in $0.1 \mathrm{M}-\mathrm{KCl}$ ) before use. The electrodes were clamped so that the reference electrode was just immersed in the overlying water and the platinum electrode was at the sediment-water interface. The sediment was then extruded upwards at $1 \mathrm{~mm}$ intervals and electrode potential readings were taken after 1 min at each depth.

Extraction of enzymes from sediment. For electron transport system (ETS) activity, a dilution of sediment in cold extraction solution was sonicated (MSE Ultrasonic Disintegrator) at an amplitude of $12 \mu \mathrm{m}$ for 2 min in an ice bath. The extraction solution contained $1.7 \%(\mathrm{v} / \mathrm{v})$ Triton X-100, $0.15 \%(\mathrm{w} / \mathrm{v})$ polyvinylpyrrolidone and $75 \mu \mathrm{M}-\mathrm{MgSO}_{4}$ in $50 \mathrm{~mm}$-Tris $/ 5 \mathrm{~mm}$-EDTA buffer, $\mathrm{pH} 7 \cdot 4$. The sample was centrifuged at $4000 \mathrm{~g}$ for $10 \mathrm{~min}$ at $0^{\circ} \mathrm{C}$ and the supernatant (enzyme extract) was then removed. All solutions were kept in ice/water baths and all manipulations before incubation were performed at a similar temperature. For malate dehydrogenase and lactate dehydrogenase, EDTA was omitted from the extraction solution and the Triton X-100 concentration was reduced to $0.02 \%$. For the protease and amylase assays, $0.1 \mathrm{M}$-phosphate buffer, $\mathrm{pH} 7.5$, was used in the solution and the Triton X-100 concentration was $0.2 \%$.

Electron transport system (ETS) activity. This was used as a measure of microbial energy-yielding metabolism in the sediments. The method used was that of Owens \& King (1975) as modified by Jones \& Simon (1979) to ensure optimum conditions for extraction of enzymes from freshwater sediments.

Malate dehydrogenase (EC 1.1.1.37) and lactate dehydrogenase (EC 1.1.1.27). These enzymes were determined by measuring the decrease in NADH fluorescence in the assay mixture. This contained $98 \mathrm{vol}$. enzyme extract (from a $5 \times 10^{-3}$ dilution of sediment), 1 vol. NADH solution (1.5 mM in Tris/EDTA buffer) and either 1 vol. $120 \mathrm{~mm}$-oxaloacetate (for malate dehydrogenase) or $1 \mathrm{vol} .120 \mathrm{~mm}$-pyruvate (for lactate dehydrogenase). Test solutions were read against controls for sediment extract fluorescence and NADH fluorescence at the initial concentration $\left(\lambda_{\text {ex }} 340 \mathrm{~nm}, \lambda_{\text {em }} 450 \mathrm{~nm}\right)$.

Protease. Protease activity was determined by incubating $2 \mathrm{ml}$ of enzyme extract with $0.5 \mathrm{ml}$ of an Azocoll suspension $\left(0.5 \%, \mathrm{w} / \mathrm{v}\right.$; Calbiochem) at $35^{\circ} \mathrm{C}$ for $3 \mathrm{~h}$. The reaction was stopped by centrifuging at $4500 \mathrm{~g}$ for $15 \mathrm{~min}$ and the absorbance of the supernatant was read at $520 \mathrm{~nm}$.

Amylase. The amylase assay was based on that of Rinderknecht et al. (1967). The substrate was amylopectin azure (Calbiochem) and the volumes, concentrations and conditions were as for the protease assay. The reaction was stopped as above, but $0.025 \mathrm{ml}$ of glacial acetic acid was then added to $2 \mathrm{ml}$ of the supernatant (final pH 3 to 4) and the absorbance was read at $595 \mathrm{~nm}$. All absorbance values were corrected for separate substrate and enzyme controls.

Direct counts of bacteria. Counts were performed by epifluorescence microscopy on black membrane filters using the procedure of Jones \& Simon (1975). Sediment samples were diluted $10^{-3}$ with membranefiltered water before staining with acridine orange at a final concentration of $10 \mathrm{mg} \mathrm{l}^{-1}$.

$A T P$. Microbial biomass was estimated by the firefly luciferin-luciferase bioluminescence method. Increased sensitivity was obtained by adopting the procedure of Jones \& Simon (1977). Extractions were performed by injecting $0.5 \mathrm{ml}$ of a $5 \times 10^{-3}$ dilution of sediment into actively boiling Tris buffer at $\mathrm{pH} 7 \cdot 8$. This procedure was sufficiently rapid to ensure that the adenylate energy charge was not altered significantly and that ATP content could be used as a biomass indicator. 


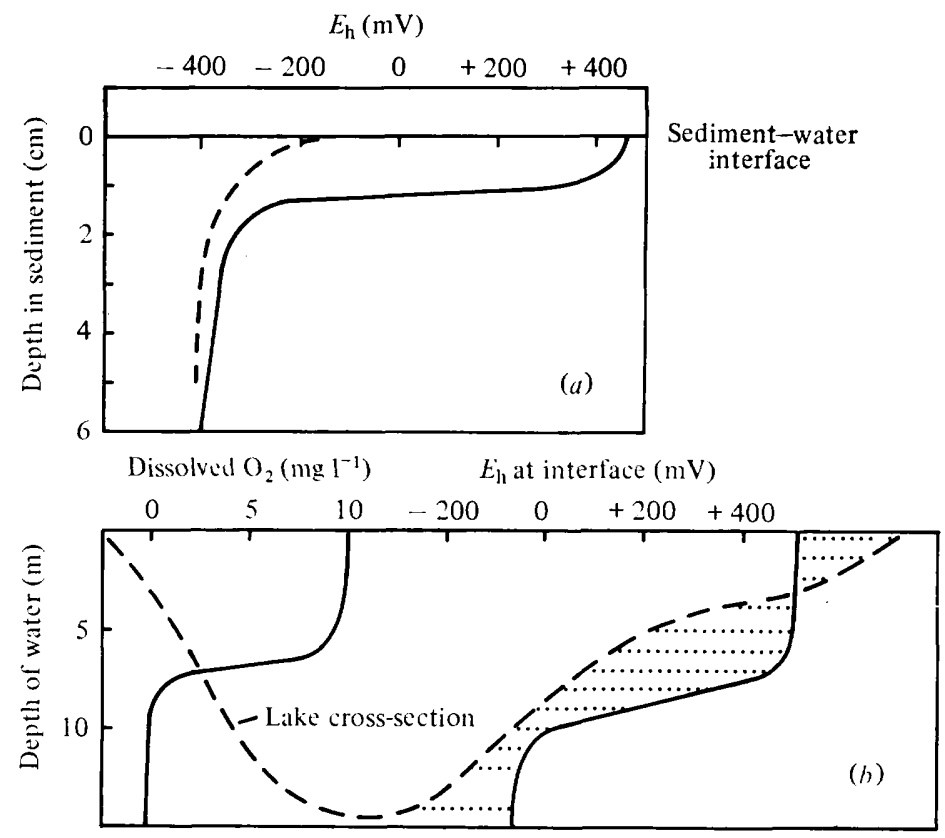

Fig. 1. Examples of $E_{\mathrm{h}}$ gradients in a shallow eutrophic lake (Blelham Tarn). (a) $E_{\mathrm{h}}$ gradients in sediment cores in winter $(-)$ and in summer $(---)$ when the hypolimnion is anoxic. (b) Crosssectional transect of a shallow lake showing the dissolved oxygen concentration in the water column and the $E_{\mathrm{h}}$ at the sediment--water interface.

\section{RESULTS AND DISCUSSION}

Some typical $E_{\mathrm{h}}$ gradients from a shallow eutrophic lake (Blelham Tarn) are shown in Fig. 1. In sediment cores, $E_{\mathrm{b}}$ decreased rapidly with depth (Fig. $1 a$ ) but the depth of the discontinuity layer depended on the season and the site at which the core sample was taken. As anoxic conditions develop in the hypolimnion the discontinuity layer in profundal sediments moves closer to the mud surface (Fig. $1 a$ ) and occasionally into the water column (Mortimer, 1941, 1942). The $E_{\mathrm{h}}$ values obtained in this study are in good agreement with those of Mortimer $(1941,1942)$ and with other more recent studies on temperate freshwater sediments. On a whole-lake scale, the $E_{\mathrm{h}}$ at the sediment-water interface will reflect the conditions in the overlying water. Thus a transect across Blelham Tarn (Fig. 1b) demonstrates the oxidizing nature of surface sediments in the littoral zone, an $E_{\mathrm{h}}$ gradient in the region of the metalimnion and more reducing surface sediments in the profundal zone. The depth of both types of gradient (i.e. within the sediment and at the sediment surface across a lake transect) will depend on the degree of turbulence in the overlying water. The discontinuity layer within the sediment is deeper in the littoral zone because of greater turbulence and surface sediment disturbance; similarly, the depth-range of the gradient at the sediment surface in Fig. 1(b) will be affected by internal water movements (seiches). I have avoided the use of the term redox (and therefore the connotation of associated specific redox couples) because the $E_{\mathrm{h}}$ measurements in the sediments represent a range of oxidationreduction reactions, and with a system such as that described in this paper, measurements are likely to be accurate only to within $50 \mathrm{mV}$. It has been demonstrated, however, that such measurements may be of value in understanding the microbiology (Cappenberg, 1974; Fenchel \& Jørgensen, 1977; Jørgensen, 1977a) and chemistry (Whitfield, 1969) of sediments.

It was possible to demonstrate changes in the activities of certain indicator enzymes with increasing depth and decreasing $E_{\mathrm{h}}$ in individual sediment cores. Although it was not possible to obtain complete recovery of added dehydrogenase enzymes from sediments, the 
Table 1. Enzyme activities in Blelham Tarn sediment samples from different depths and having different electrode potentials

$\begin{array}{cccc}\overbrace{\text { Depth }(\mathrm{mm})} & \text { Sample } & \begin{array}{c}\text { Lactate dehydrogenase* } \\ (\mu \text { mol NADH } \\ \text { oxidized h-1 }\end{array} & \begin{array}{c}\text { Malate dehydrogenase } \\ 0-5\end{array} \\ \begin{array}{ccc}E_{\mathrm{h}}(\mathrm{mV}) \\ +375\end{array} & 6 \cdot 3 & 2 \cdot 2 \\ 5-10 & +180 & 5 \cdot 0 & 2 \cdot 6 \\ 10-20 & +90 & 7 \cdot 6 & 1 \cdot 4 \\ 60-70 & -70 & 7 \cdot 9 & 1 \cdot 3 \\ 0-10 & +460 & 0 \cdot 7 & 13 \cdot 0 \\ 25-35 & +340 & 1 \cdot 5 & 9 \cdot 4 \\ 40-45 & +270 & 4 \cdot 3 & 2 \cdot 6 \\ 45-50 & +150 & 6 \cdot 1 & 1 \cdot 1 \\ 55-60 & +140 & 6 \cdot 3 & 1 \cdot 5 \\ & & & \end{array}$
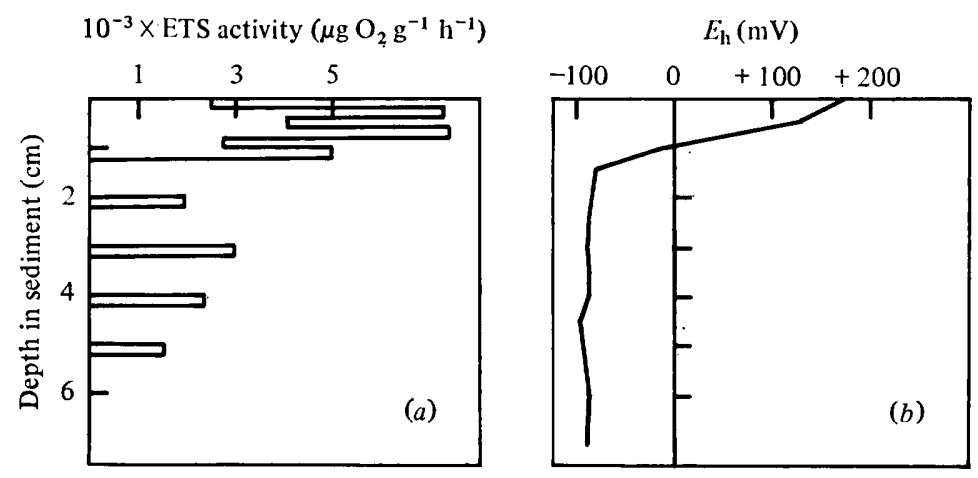

Fig. 2. Energy metabolism along an $E_{\mathrm{h}}$ gradient in sediment from the North Basin of Windermere. (a) Electron transport system activity. (b) Electrode potential.

yield did not change in a systematic manner with $E_{\mathrm{h}}$, and would not, therefore, account for the results obtained. The methods of enzyme extraction used were chosen after testing several combinations of buffer and extraction solution concentrations (particularly detergent and EDTA) and were found to give greatest recoveries of each enzyme. The actual values for dehydrogenase enzymes varied from site to site but the most consistent trend observed was a steady increase in lactate dehydrogenase activity and an attendant decrease in the malate dehydrogenase:lactate dehydrogenase ratio with decreasing $E_{\mathrm{h}}$ (Table 1). The enzyme activities indicated a switch from an aerobic, tricarboxylic acid cycle-based metabolism to a fermentative one. These particular enzymes were chosen because pure culture studies had demonstrated considerable changes in their concentration in response to oxygen tension and $E_{\mathrm{h}}$ (Gray et al., 1966; Wimpenny, 1969). Such enzyme assays may, however, only be used to indicate general trends, largely because of the difficulties involved in obtaining reliable results from heterogeneous material such as sediment. Background levels of u.v.-absorbing materials could account for as much as $70 \%$ of the signal if the $\mathrm{NADH}$ was determined spectrophotometrically. This background was reduced to about $15 \%$ if the more specific spectrofluorimetric procedure was used, but this advantage was often counterbalanced by the degree of quenching which was observed, particularly in the reducing sediments. A range of known concentrations of NADH was therefore added to the samples to act as internal standards and to ascertain linearity of response. In addition, each sample was incubated with NADH as sole substrate to correct for NADH oxidation. 


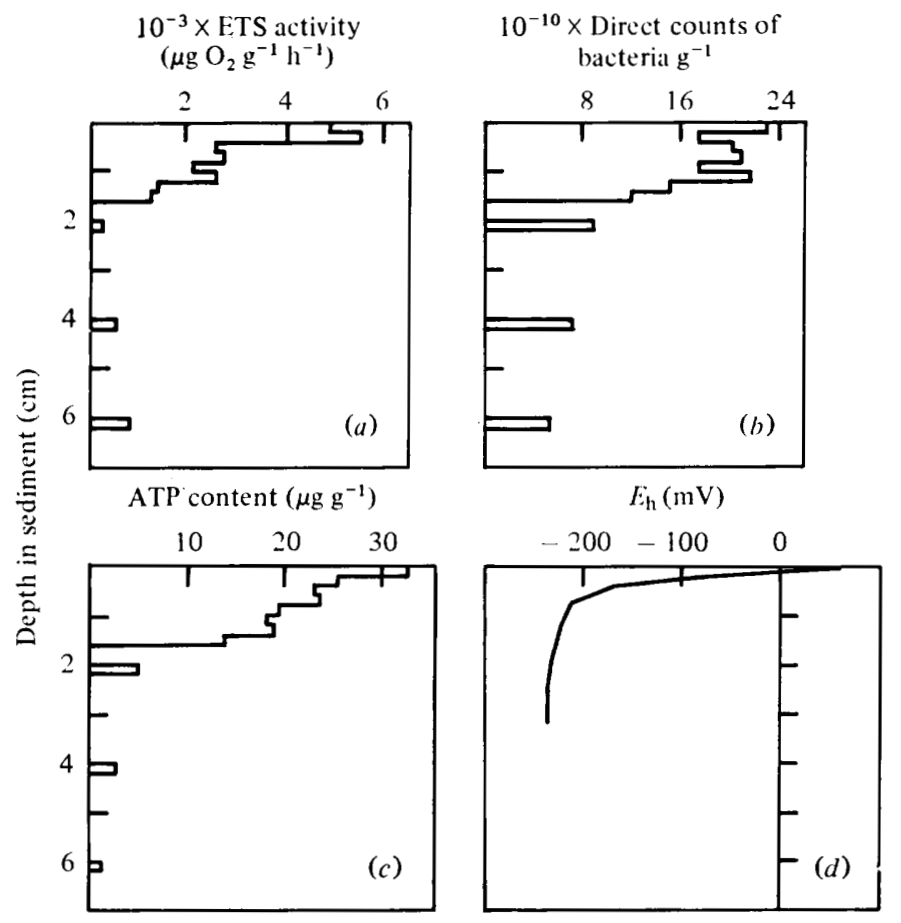

Fig. 3. Microbial activity, ATP content and bacterial numbers along an $E_{\mathrm{h}}$ gradient in sediment from the anoxic hypolimnion of Blelham Tarn. (a) Electron transport system activity. (b) Direct counts of bacteria. (c) ATP content. (d) Electrode potential.
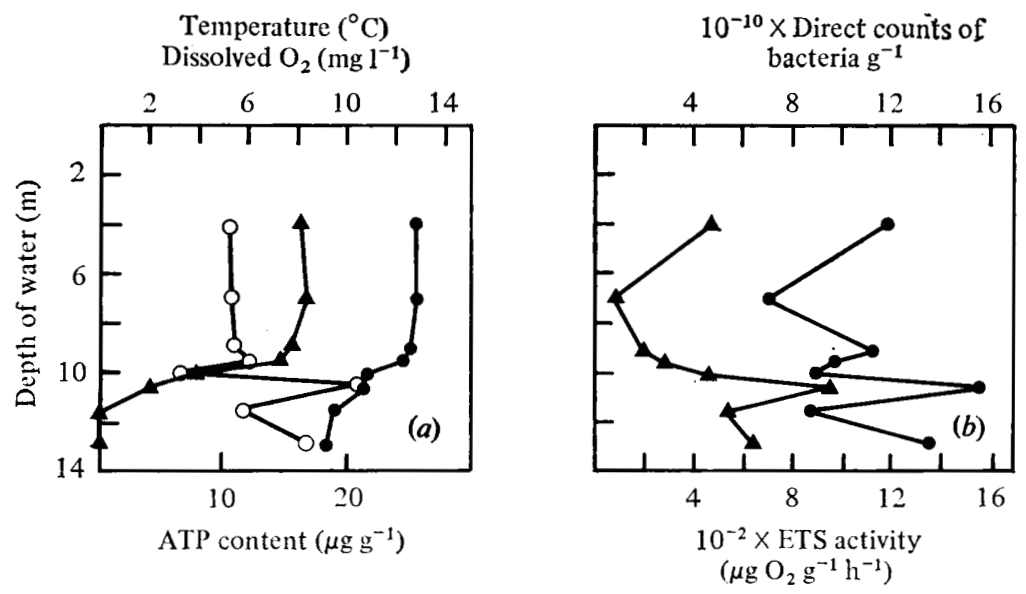

Fig. 4. Microbial activity, ATP content and bacterial numbers in surface sediment on a transect of Blelham Tarn from oxic littoral sediments to anoxic profundal sediments. (a) Temperature (O), dissolved oxygen concentration ( $\mathbf{A})$ and ATP content $(O)$. (b) Direct counts of bacteria (O) and electron transport system activity $(\boldsymbol{\Delta})$.

An attempt was then made to obtain a general estimate of the enzymes involved in microbial energy metabolism in the sediment by measuring the electron transport system (ETS) activity. Although microbial activity, biomass and numbers of most micro-organisms generally decreased with depth in Windermere sediment, it was possible to demonstrate peaks of activity associated with the $E_{\mathrm{h}}$ discontinuity layer (Fig. 2). These peaks were observed 


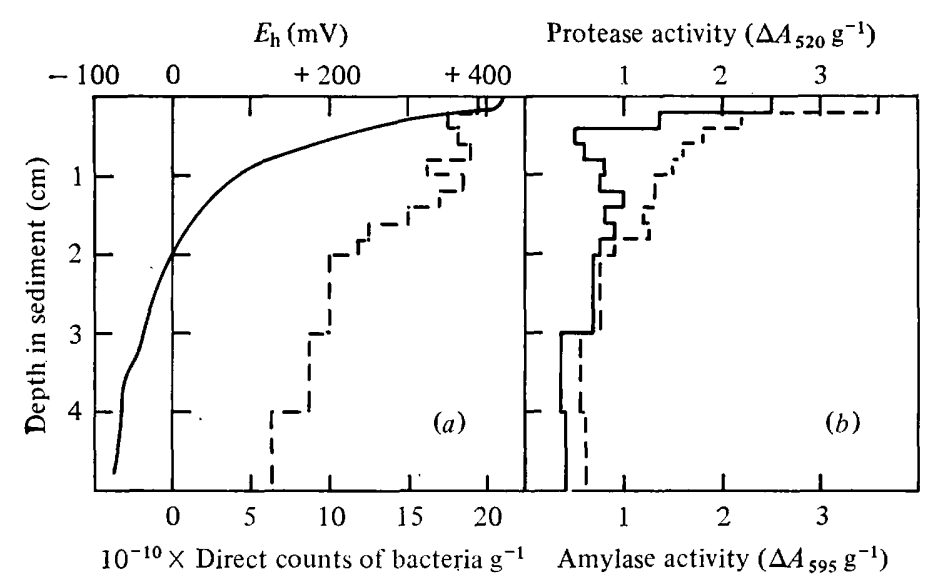

Fig. 5. Activity of hydrolytic enzymes and numbers of bacteria along an $E_{\mathrm{h}}$ gradient in sediment from Windermere. $(a) E_{\mathrm{h}}(-)$ and direct counts of bacteria $(---)$. (b) Protease activity $(-)$ and amylase activity $(---)$.

at 2 to $4 \mathrm{~mm}, 6$ to $8 \mathrm{~mm}$ and 10 to $12 \mathrm{~mm}$ as $E_{\mathrm{h}}$ changed from +150 to $-100 \mathrm{mV}$. Such pronounced peaks were not observed when the $E_{\mathrm{h}}$ gradient was near the sediment surface, as in Blelham Tarn towards the end of summer (Fig. 3). The decrease in activity with depth (Fig. $3 a$ ) did not always correspond to decreases in bacterial numbers (Fig. $3 b$ ) or ATP content (Fig. $3 c$ ). Although all three variables decreased with depth, the activity per bacterium or per unit ATP biomass was not constant. The ETS activity observed was two to three orders of magnitude greater than that in marine sediments (Wieser \& Zech, 1976; Vosjan \& Olanczuk-Neyman, 1977) but small differences in analytical technique can considerably affect the sensitivity of the assay and such comparisons may not, therefore, be valid.

It was also possible to demonstrate the importance of $E_{\mathrm{h}}$ gradients as sites of increased microbial activity on a whole-lake scale (Fig. $1 b$ ). Analyses from a transect of Blelham Tarn during late summer showed that the dissolved oxygen concentration fell from 8 to $0 \mathrm{mg} \mathrm{l}^{-1}$ in the metalimnion (Fig. $4 a$ ) and that in this region peaks of bacterial numbers, ATP and microbial activity were observed in the surface sediment (Fig. $4 b$ ). Once again the ratio of activity to biomass or numbers was not constant. The results confirmed earlier observations on the occurrence of large crops of filamentous sulphur bacteria and cyanobacteria in this zone.

Microbial hydrolytic activity, however, (e.g. the hydrolytic cleavage of proteins and polysaccharides) was not particularly associated with the $E_{\mathrm{h}}$ discontinuity layer. Protease and amylase activity were maximal at the surface of the Windermere sediment and decreased steadily with depth (Fig. $5 b$ ) even though bacterial numbers showed no such rapid decline (Fig. 5a). Microbial hydrolytic activity, in contrast to energy metabolism, appeared to be greatest at the sediment-water interface, i.e. at the point where the substrate concentration, in the form of detritus and sedimented algal remains, might be expected to be highest.

It has already been suggested that $E_{\mathrm{h}}$ gradients provide conditions conducive to microbial growth and activity (Fenchel \& Jørgensen, 1977). Karl (1978) has demonstrated peaks of biomass and higher adenylate energy charge values at the $\mathrm{O}_{2}$-sulphide interface in the water column, as well as sub-surface peaks in the sediment of the Black Sea. This paper demonstrates that, in contrast to the conventional picture of a steadily decreasing microbial population and activity with depth of sediment, energy metabolism in particular is associated with, and maximal on, sub-surface $E_{\mathrm{h}}$ gradients. This has been shown over several metres, on a whole-lake transect of surface sediments, as well as over a few millimetres in a sediment 
profile. Such gradients may occur on an even smaller scale. Jørgensen (1977b), for example, has shown that obligate anaerobes such as Desulfovibrio can grow within sediment pellets (50 to $200 \mu \mathrm{m}$ diam.) in the oxidized surface layers. The $\mathrm{H}_{2} \mathrm{~S}$ produced by them diffused into the interstitial solution and was oxidized by sulphide oxidizers (such as Beggiatoa spp.) before any detectable accumulation took place. Although attempts to measure such fine $E_{\mathrm{h}}$ gradients with microelectrodes failed during this study, it is possible that histotopochemical techniques such as those used by Garlichs et al. (1974) might provide information on microbial metabolism within such small particles.

I am very grateful to B. M. Simon, J. S. Collis, S. Ellis and S. Irwin who have provided excellent technical assistance at various stages of this work.

\section{REFERENCES}

CAPPEnberG, T. E. (1974). Interrelations between sulfate-reducing and methane-producing bacteria in bottom deposits of a fresh-water lake. 1. Field observations. Antonie van Leeuwenhoek 40, 285295.

Collins, V. G. \& Willoughry, L. G. (1962). The distribution of bacteria and fungal spores in Blelham Tarn with particular reference to an experimental overturn. Archiv für Mikrobiologie 43, 294-307.

Fenchel, T. M. \& Jørgensen, B. B. (1977). Detritus food chains of aquatic ecosystems: the role of bacteria. Advances in Microbial Ecology 1, 1-58.

Garlichs, U. A., Brandau, H. \& Bössmann, K. (1974). Histotopochemical determination of metabolic activity of carbohydrate metabolism in plaque from sound and carious enamel. Caries Research 8, 234-248.

Gray, C. T., WimpenNy, J. W. T., Hughes, D. E. \& Rossman, M. R. (1966). Regulation of metabolism in facultative bacteria. 1. Structural and functional changes in Escherichia coli associated with shifts between aerobic and anaerobic states. Biochimica et biophysica acta 117, 22-32.

Johnston, D. W. \& Cross, T. (1976). The occurrence and distribution of actinomycetes in lakes of the English Lake District. Freshwater Biology 6, 457463.

JoNES, J. G. (1972). Studies of freshwater bacteria: association with algae and alkaline phosphatase activity. Journal of Ecology 60, 59-75.

JONES, J. G. (1976). The microbiology and decomposition of seston in open water and experimental enclosures in a productive lake. Journal of Ecology 64, 241-278.

JONES, J. G. (1977). The effect of environmental factors on estimated viable and total populations of planktonic bacteria in lakes and experimental enclosures. Freshwater Biology 7, 67-91.

JoNES, J. G. (1978). The distribution of some freshwater planktonic bacteria in two stratified eutrophic lakes. Freshwater Biology 8, 127-140.

JONES, J. G. \& SiMON, B. M. (1975). An investigation of errors in direct counts of aquatic bacteria by epifluorescence microscopy, with reference to a new method for dyeing membrane filters. Journal of Applied Bacteriology 39, 317-329.

JoNES, J. G. \& Simon, B. M. (1977). Increased sensitivity in the measurement of ATP in freshwater samples with a comment on the adverse effect of membrane filtration. Freshwater Biology 7, 253260.

JoNES, J. G. \& Simon, B. M. (1979). The measurement of electron transport system activity in freshwater benthic and planktonic samples. Journal of Applied Bacteriology 46, 305-315.

JøRGENSEN, B. B. (1977a). Distribution of colorless sulfur bacteria (Beggiatoa spp.) in a coastal marine sediment. Marine Biology 41, 19-28.

JøRGENSEN, B. B. (1977b). Bacterial sulfate reduction within reduced micro-niches of oxidized marine sediments. Marine Biology 41, 7-17.

KARL, D. M. (1978). Distribution, abundance, and metabolic states of microorganisms in the water column and sediments of the Black Sea. Limnology and Oceanography 23, 936-949.

MaCKereth, F. J. H. (1964). An improved galvanic cell for determination of oxygen concentrations in fluids. Journal of Scientific Instruments 41, 38-41.

Mortimer, C. H. (1941). The exchange of dissolved substances between mud and water in lakes. I and II. Journal of Ecology 29, 280-329.

MORTIMER, C. H. (1942). The exchange of dissolved substances between mud and water in lakes. III and IV. Journal of Ecology 30, 147-201.

Overbeck, J. (1968). Prinzipielles zum Vorkommen der Bacterien in See. Mitteilungen der Internationalen Vereinigung für theoretische und angewandte Limnologie 14, 134-144.

OVERBECK, J. (1975). Distribution pattern of uptake kinetic responses in a stratified eutrophic lake. Verhandlung der Internationalen Vereinigung für theoretische und angewandte Limnologie 19, 26002615.

OWENS, T. G. \& KING, F. D. (1975). The measurement of respiratory electron-transport-system activity in marine zooplankton. Marine Biology 30, 27-36.

Rinderknecht, H., Wilding, P. \& HaVerback, B. J. (1967). A new method for the determination of $\alpha$-amylase. Experientia 23, 805.

Vosjan, J. H. \& OlanCZUK-Neyman, K. M. (1977). Vertical distribution of mineralization processes in tidal sediment. Netherlands Journal of Sea Research 11, 14-23.

WHITFIELD, M. (1969). $E_{\mathrm{h}}$ as an operational parameter in estuarine studies. Limnology and Oceanography 14, 547-558. 
WIESER, W. \& ZECH, M. (1976). Dehydrogenases as tools in the study of marine sediments. Marine Biology 36, 113-122.
WIMPENNY, J. W. T. (1969). Oxygen and carbon dioxide as regulators of microbial growth and metabolism. Symposia of the Society for General Microbiology 19, 161-197. 